\title{
The Empowerment of Indigenous Women as a Factor in the Socio-Productive Development of a Rural Community
}

\author{
Yeimy Alejandra Izquierdo Cujar, Máster en Gestión Pública y Gobiernoํㅡ, Carlos Ramón Vidal Tovar, Doctor en \\ Ciencias ${ }^{1,2}$, Yimy Gordon Hernández, Doctor en Ciencias Gerenciales ${ }^{2}$, Giovanna Elvira Angulo Blanquicett, \\ Magister en Educaciòn ${ }^{1}$, Pedro José Fragoso Castilla, Doctor en Medicina Tropical ${ }^{2}$, and Carlos Alberto Gutiérrez De \\ Piñeres Rocha, Magister en Diseño, Gestión y Direccion De Proyectos ${ }^{1}$ \\ ${ }^{1}$ Universidad de Santander - UDES, Colombia, aleja2527@gmail.com,car.vidal@mail.udes.edu.co, \\ gangulo@valledupar.udes.edu.co,walframio ciencia@yahoo.com \\ ${ }^{2}$ Universidad popular del Cesar - UPC, Colombia,carlosvidal@unicesar.edu.co,yimygordon@unicesar.edu.co, \\ pedrofragozo@unicesar.edu.co
}

\begin{abstract}
This article discusses the point of view of women's empowerment and its impact on public policy. Also mentions the importance of the role of indigenous women in rural and captures the scenario in the municipality of Pueblo Bello, Cesar, where the indigenous community Jewrwa. For the above, research is developed from the application of the emerging paradigm, for which a dialectical synthesis is assumed through the use of qualitative and quantitative methods in a complementary way. It is developed in three phases: the first consists of field visits to interview 5 groups of indigenous women located in the rural area of "Pueblo Bello" - Colombia. In addition, 5 indigenous women from the same region, successful in their professional lives, are interviewed. The second phase consists of the search and systematization of documents from multiple sources of information consulted in the year 2020 in search engines such as: Scielo, Dialnet and Google Scholar, and the third phase is a comparative analysis of the sources of information mentioned above. Data analysis was carried out by structuring thematic categories related to the empowerment of rural indigenous women. Empowerment from the intuitive perspective to drive positive changes in the situations they live, and even the political organization to transform those relationships. Hence, in order to promote processes of empowerment, it is necessary to work on the construction of the autonomy of rural indigenous women. Traditionally, indigenous women are in charge of the care work, learned by inheritance and pre-established social constructs, leaving themselves in the last place, at the service of others.
\end{abstract}

Keywords - Empowerment, Indigenous Women, SocioProductive, Development, Rural Areas, Community

\section{INTRODUCTION}

The empowerment of women arises when in the seventies the productive participation of women was at the lower levels of the economic system, it was considered as a human capital of low utility for which its integration into productive life was necessary. Then, in the eighties, in the countries qualified as" third world" of the moment, gender inequalities, class differences, and ethnic diversity are recognized [1]. At this

Digital Object Identifier (DOI):

http://dx.doi.org/10.18687/LEIRD2021.1.1.50

ISSN: 2414-6390 ISBN: 978-958-52071-9-6 point, women are analyzed as a factor of utmost importance and dynamic subject for change and it is when women's empowerment is proposed as a strategy to overcome inequality, necessary in the interaction between men and women in a productive system. An empowered woman also has greater control over her life, her home and her community. Although the term empowerment refers to greater power in all areas, both external and internal, the document only evaluates whether women are empowered in external terms: in their home and in their community [2].

In this sense, empowerment is an acquired competence, different for each person and group according to their historical, social, political and cultural environment, makes women an active subject for their integration and recognition towards the change of dominant cultural structures. That is, empowerment allows women to organize groups with a predetermined beginning and end to break with subordination according to location, that is, acquire power in their life dynamics [3]. It should be taken into account that women have been educated in oppressive environments where female subordination is seen as normal, correct and natural [4]. Where it is difficult to autonomously identify the damage and harmful impacts of power relations on personality and close and community relationships. That is why empowerment must often be promoted by agents of change [5].

For indigenous women is not an easy process because it leads to strengthening and developing skills, abilities, and skills to get highlight of every Indian woman his qualities and from the individual to reach to encourage changes in groups that can positively affect their communities, this process of transformation of indigenous women by the way of the residence, fails to meet the goal of training indigenous women, who can influence and drive your life and the lives of their communities; therefore, it also requires addressing strategies to achieve effective equality in all areas of life [6].

In this way, the current dynamics integrated empowerment in the framework of a developed society, is highlighted as elements of the framework, the awareness of the individual and 
collective capacities, as well as in the current situation of the economic environment, social, political, and environmental. In turn, the acquisition and development of skills that enable participation, individual and/or group, in processes of decision-making on important issues, and the development of a favorable environment that establishes the formal and informal institutions, where you are guaranteed access to information and to facilitate participatory processes of decision making [7].

In this sense, despite the broad international consensus on the fundamental role of indigenous women in the eradication of hunger, malnutrition, social problems, among others. In a world dominated by men, poor in a system that has historically marginalized them and indigenous in societies that discriminate and stigmatize. Therefore, the empowerment that has been developed globally by indigenous women is a precondition for achieving sustainable development [8].

Continuing from the perspective of women's labor participation, it is described that they receive less salary for their participation in the labor market; which dispenses, that they do not receive any remuneration for housework that, in addition, this means a reduction in their time to train as professionals; in cultures of strong patriarchal tradition they are the last to feed themselves and have more difficulties in accessing productive resources [9].

According to the report of the International Labour Organization issued during the sixteenth session of the United Nations Permanent Forum on Indigenous Issues, they describe the importance that decent work can play in empowering indigenous women and men. It should be noted that in their role as workers, entrepreneurs and guardians of their traditions, indigenous women play a vital role in the economic, social, cultural and environmental life of their communities and societies. On the other hand, indigenous women are generally among the poorest of the poor, discriminated against because of their indigenous status and because of their female status [10].

This article discusses the point of view of women's empowerment and its impact on public policy. Also mentions the importance of the role of indigenous women in rural and captures the scenario in the municipality of Pueblo Bello, Cesar, where the indigenous community Jewrwa possesses a cultivation of coffee and together with other growers have structured a partnership to an end of progress, community and give those possibilities of education, participation, leadership and empowerment to men and influential women of the community.

\section{METHODOLOGY}

The research is developed from the application of the emerging paradigm, for which a dialectical synthesis is assumed through the use of qualitative and quantitative methods in a complementary way. More not exclusive, since the collection of information and the analysis of results is not limited to the forms and sources of information. For the above, reference is made to the contribution of the experience of women belonging to the indigenous communities of the municipality of Pueblo Bello, Colombia. As a fundamental part of the construction of knowledge. Likewise, the same level of importance is given to the information obtained from multiple sources of information consulted in the year 2020 in search engines such as: Scielo, Dialnet and Google Scholar, among others [11].[12]. Documents by authors from different countries were reviewed through theses, books, articles and studies, which allowed a critical reading and an objective analysis on women's empowerment, the development of indigenous women and gender and ethnic inclusion policies

For the collection of information, the instruments are applied in three phases: the first consists of field visits to interview 5 groups of indigenous women located in the rural area of "Pueblo Bello" - Colombia. In addition, 5 indigenous women from the same region, successful in their professional lives, are interviewed. The second phase consists of the search and systematization of documents and the third phase is a comparative analysis of the sources of information mentioned above. The analysis of the data was carried out by structuring thematic or conceptual categories based on the order of importance of the factors related to the empowerment of rural indigenous women. With the above, the results of this work are ordered, interpreted and presented through what has been proposed by multiple authors [13]. [14].

\section{ANALYSIS OF RESULTS}

\section{A. Indigenous women and empowerment}

The aim is to highlight the work of rural indigenous women in the various cultural, social and economic activities of their community, thereby promoting the empowerment of this group for personal and community development around the economic activities they lead.

The achievement of gender equality and the empowerment of women has become one of the greatest challenges worldwide, as rights such as education, women's political participation in different scenarios, physical and economic autonomy, among others, are not fully guaranteed by countries [15].

Currently, the perception of women's inferiority is widespread both in developed countries and in those that are still growing, not only giving an unequal treatment or position, but also detracts from the work and the contribution of women [16].

In Colombia there has been an uprising by the female gender, in recent decades prepared women have held public positions and aspired to the highest political ranks based on their knowledge and experiences have contributed to decisionmaking and beneficial actions for their communities.

That said, the empowerment in the case of a decision to overcome adversity, to take word and place in any situation, 
the empowerment and leadership of women born in the heart of the home and the community that is why in this article makes recommendations to empower a group of indigenous women, which together with the inequality from its roots, where their duties are important within the community, but very little take the word to express opinions, make decisions, where higher education for a girl is a risk as she is forced to leave her land to expose herself to an even more crude and exclusive world.

The current presence of indigenous women in leadership positions (at the local, regional and national levels) - even if not very significant - suggests that they have been gaining ground in politics. However, this shows at the same time that this terrain that has been won is and has been the product of the different works and struggles carried out by indigenous women [17].

\section{B. Rural indigenous women}

Indigenous women have worked for the formation of an organized network that leverages their integration and recognition as indigenous women farmers, in the different fields, coffee, cocoa, vegetables, and seeds among other products.

To be taken into account in the development of programs and projects by public corporations, but also private ones seeking national and international support. In order to achieve their objectives of integration and active social participation, indigenous women emphasize concrete proposals regarding the problems that affect them.

The components of ethnic identity are even broader than those proposed by some authors such [18]. Who is fundamentally based on the daily use of the indigenous language as a form of communication in close relationships, as a means of socialization and generational transmission of the main cultural values of the group. Goes further, indicating that ethnic or cultural identity "...is the nexus between individuals who identify with norms, values and patterns of behavior according to their gender, social class, age, etc., based on symbols, common beliefs about the same origin, specificity and destiny of the group". This author highlights gender identity as one of the bases that constitute the identity of people and that are reflected in their practices [18].

On the other hand the concept "culture" is defined by as the set of activities, material and spiritual products that distinguish one particular society from another. It does not raise the superiority or inferiority of any cultural manifestation, it is accepted that any cultural element is the result of a specific social dynamic and responds to collective needs; in addition, it underlines the following elements of culture [18]:

As a collective process of creation and recreation.

As an accumulated inheritance from previous generations.

As a set of dynamic elements that can be transferred from group to group and, where appropriate, accepted, reinterpreted or rejected by different social groups.
The customs and social organization of the indigenous peoples existing currently in Mexico are not isolated from the so-called "national culture", but are in constant interaction and relationship with the rest of society, have oversized forms of social organization and strategies of reproduction throughout the story and integrated cultural elements external which are incorporated permanently and, at the same time, influence on the national culture.

However, the problems of extreme poverty that characterize particularly to the regions, and the indigenous population indicate that face structural conditions that limit the conservation of resources and the exercise of their rights, whose reaction is expressed in various attempts to change by means of manifestations ranging from the formation of organizations of men's, women's and mixed for the defense of its territory, the production and marketing of their products, the procurement of services, care, and management of forests, health care and other, even armed movements such as the one in Chiapas, which began in 1994.

The peasant indigenous population is generally described as highly vulnerable population groups whose physical and cultural survival is in serious danger; however, indigenous policies have been criticized for having paternalistic or confrontational orientation and for not taking the opinions and suggestions of the population indigenous.

Therefore, sustainable development must also consider the preservation of the cultural identity of the population, since an economic growth that ignores cultural identity is, after all, profoundly destructive, since it is impossible to imagine biodiversity without "cultural diversity", for which it is accepted that humanity is made by multiple cultures. The loss of a culture is an irreparable loss for humanity [19].

Thus, cultural sustainability is as essential as environmental sustainability; if sustainable development is understood as an ethical choice, then we must also recognize that this can only occur between freedom, justice and equity.

The participation of indigenous women in social movements, organizations and economic projects has helped to make them visible within their ethnic groups and communities and abroad in relations with the State, but this still needs to be translated into their being considered as real subjects of social policies and economic projects and that their activity is not seen as complementary to family income, as is usually seen in women's work.

The empowerment strategy, because of its implications in the construction of new forms of power and its redistribution, based on the analysis of social relations between the genders, is necessary for the construction of equity in development. In this sense, the aspects that most support the sustainability of the organizational and empowerment processes of indigenous women's organizations with ecotourism social enterprises, as is the case of the Masehualsiuamej Mosenyolchicauanij.

In this way, it is possible to contribute to the global sustainability process from local spaces and to the 
sustainability of empowerment strategies points out [19]. By the above, it states that it cannot be separated by the process of empowerment of sustainability that involves democratization, freedom and equality among the subjects of actions at local, regional or global, in addition to the care and preservation of cultural identities and knowledge that support the cultural diversity, biodiversity and its conservation, since the social subjects and the society as a whole who will be able to support the process of sustainable development, in spaces from local and regional related movements more spacious.

This is if one considers that a constitutive aspect of the sustainable development process is gender and generational equity, as well as elements of resource management and distribution [19].

\section{c. Use Empowerment of rural indigenous women}

Starting from the definition of empowerment focused from the gender perspective as a driving tool for the development of the local economy; In principle, this issue of the empowerment of the woman emerges from the literature of Women in Development (MED) and Gender in Development (GDE) in the seventies, in the first describes the study of women as a human capital wasted, by which it was sought incorporation into the productive life where it is identified as a problematic of productive participation of women, were in the lower levels of the economic system. In the second approach GDE places it in the eighties, after the recognition of the inequalities of gender, classes and ethnicity in the countries that at that time made up the "third world". At that moment, women are seen as active subjects and drivers of change and women's empowerment is proposed as a strategy to overcome the limitations of the MED approach [20].

Based on the above-mentioned approaches, empowerment is defined as a strategy to overcome any inequality that may exist between a man and a woman in the productive sphere.

In contrast to this, there is the position of those who refer to empowerment with increased participation of women in access to control of material, intellectual and ideological resources that allow to reach a full contribution to the construction of society that allows their participation on equal terms with men, both in economic and political life and in decision-making at all levels. What it means for women is the gain in self-esteem, education, information and rights, that is: power [21].

Empowerment is, then, an acquired skill which allows women both integration and recognition, that is, as an active subject for the change of authoritarian cultural structures, or of subordination that may exist within their society. That is, empowerment will be a tool that will allow organizing women's groups to raise women's consciousness upwards to challenge their obedience. In this way, the concept of power can act as coercive action in social relations [4].

It is important to emphasize that empowerment is not a linear process, with a predetermined beginning and end, but is different for each person and group according to their sociohistorical, political and cultural context, and according to the location of subordination in the personal, family, community, national, regional and global [3].

Regarding external support to empowerment processes, it should be considered that women have been educated in oppressive contexts where female subordination is seen as right and natural, so it is difficult to autonomously identify the harmful consequences of power relations in personality and in close and community relationships. That is why empowerment must often be promoted by agents of change. The focus of the empowerment of women may be an appropriate tool to articulate the theoretical advances of feminist thought with the practices of awareness and organization of women at the community level, promoting a synergistic relationship between the two, and seeking to stimulate especially the collective action of women who are excluded, due to the overlap of oppressions, that becomes more urgent efforts to exercise citizenship with decision-making capacity in the private and in the public, advancing on the horizon of self-determination [5].

Therefore, taking into account these definitions, we can say broadly that the process of empowerment allows people to become aware of the situation in which they live, and that from this perception on its context, to develop their capacity for change -that is to say, to actively participate in the process of transformation. However, it should be noted that, despite being frequently associated with strategies for the development of vulnerable groups and the struggle for gender equality, this concept is quite complex, as it has multiple interpretations and applications.

An example of the diversity of its uses is the current use of it in the human resources management of private companies. Within the business sphere, "empowering" means delegating power and authority to subordinates and giving them the feeling that they own their own work [22]. [23]. that said, in business language, it is a strategic tool whose objective is to develop leadership skills within a team, but without altering existing hierarchies. From a perspective quite different from that used by women's organizations or associations that work for the development of vulnerable groups. From a gender perspective, empowerment involves two types of change: individual and collective. Empowerment is understood as a process of overcoming gender inequality, to achieve this, we seek that women recognize that the model of society in which we live still perpetuates their discrimination.

Consequently, in order to achieve empowerment, it is essential to question existing social structures, since change cannot arise from a condition of resignation to inequalities. Finally, it is appropriate to point out that empowerment is an individual and internal process, that is, that no one has the capacity to empower others. As a result, it is a different procedure for each person or group according to their biography, context and history. Despite the fact that it's personal. 
Empowerment has become a central concept in the discourse of the social sciences: multiple authors define it as a process, as a product, as an approach or as an order, which has implications on the individual, the organizational, sociological, economic and political. Therefore, I understand empowerment as the process that allows sociopolitical impact within the social, economic and political dimensions, and from the personal and collective spheres, and that can be an alternative to achieve development and improve the living conditions of a population.

Based on this concept, it was considered relevant to retake elements of community psychology, understanding empowerment as the process by which communities gain capacities to intervene in the socio-political, on issues that influence their quality of life. Empowerment starts from the orientation of the values of community psychology, in which the interest is directed specifically to the mutual influence that occurs between the person and the environmental system in which it develops, which allows to broaden the concept to the right of people to be different. Therefore, diversity is another of the principles assumed by empowerment. Related to this principle, cultural relativity is also advocated, which implies understanding how people

They build their reality, that is, how they organize and interpret the world in which they live and their daily life. Thus, participation, decentralization and empowerment have different roles, but at the same time are complementary processes.

Participation is seen as a process that articulates different sectors of society and influences social structures. Decentralization, from the community level, can be the return of resources and power to the authority. And empowerment is understood as a process that allows empowering the sector with less possibilities to access it, so it promotes inclusion. These actions, at some point, can confuse participation with the notion of empowerment, for example: if in a community there are participation programs, they can be an effective instrument to promote empowerment; this will depend on the use of this tool, however if these are only in political or superficial terms, then empowerment will hardly be achieved.

Empowerment implies a critical and active participation that cannot be confused, at any time, with a simple "presence or assistance" during a decision-making process. The complex reality experienced by indigenous communities or certain social sectors and the global and national economic situation that persists in these times make it necessary to retake effective mechanisms that incorporate individual and collective components (individuals and groups).

However, if the indigenous population suffers from this phenomenon of poverty, it could be called an excluded sector. Until now, the concept of empowerment has not been isolated from the reality of life of the most excluded populations; it is a very complex concept, but it is also indispensable as a means to combat or counteract poverty and the transformation of the reality of life of a population in general, that will allow for the increasing opportunities and capabilities of individuals (groups, communities), to express their choices, and in turn, transform them into activities and desired outcomes.

In some multicultural countries with community experience of autonomous power, as in the case of Guatemala, the spaces of community and local power are mainly indigenous mayors 'offices, communal mayors' offices and councils of elders, among others. However, at the same time, there are spaces of power outside the indigenous peoples ' scheme, spaces of "formal" power in the structure of the states, such as municipalities, town councils, development councils, departmental governorates, etc. In which the participation and presence of indigenous peoples has been steadily increasing in recent years.

If we translate the concepts of empowerment into an indigenous community experience, empowerment can be approximated to the actions carried out by the different organizations of a community. For example, a group of women who feel empowered to participate in regional, departmental and national organizations representing the female sector. At this point, we conclude that empowerment, from the perspective of the indigenous community, is related to the development of a consciousness that can bring power through participation, where relationships can arise that change power in their favor, and in which control over physical, human and financial resources is sought [24].

In consequence, the entrepreneur, in this case indigenous women, make use of the factors of production to establish a strategy that allows you to achieve competitive advantages for themselves and position themselves in the markets, this could lead to the sustainability of new businesses created, or the expansion of existing companies; for this, the entrepreneur seeks the continuous improvement and innovative, with moderate risk aversion, accept responsibilities, plan long-term and have high motivation to the results. That is, they are in constant introduction of innovations and search for opportunities to generate new wealth, which is why they are creative intermediaries that facilitate the exchange between suppliers and demand of goods and services.

For this to be a reality, it is necessary to have the skills and abilities to identify opportunities, specify the necessary resources, have the team that complements the skills of the leader; in order to create, or build something new, or start a company that will create value for the economy by generating work for him and often for another. However, there are those who consider that entrepreneurship by necessity is a sign of poverty and only entrepreneurship by opportunity generates growth, since this implies innovation and efficiency as tools for the development of new markets and the sustainability of economic entities [25].

\section{Territorial public policy and empowerment of women}


The empowerment of women arises when in the seventies the productive participation of women was at the lower levels of the economic system, it was considered as a human capital of low utility for which its integration into productive life was necessary. Then, in the eighties, in the countries qualified as" third world" of the moment, gender inequalities, class differences, and ethnic diversity are recognized [26]. At this point, women are analyzed as a factor of utmost importance and dynamic subject for change and it is when women's empowerment is proposed as a strategy to overcome inequality, necessary in the interaction between men and women in a productive system. An empowered woman also has greater control over her life, her home and her community. Although the term empowerment refers to greater power in all areas, both external and internal, the document only evaluates whether women are empowered in external terms: in their home and in their community [27].

In this sense, empowerment is an acquired competence, different for each person and group according to their historical, social, political and cultural environment, makes women an active subject for their integration and recognition towards the change of dominant cultural structures. That is, empowerment allows women to organize groups with a predetermined beginning and end to break with subordination according to location, that is, acquire power in their life dynamics [3]. It should be taken into account that women have been educated in oppressive environments where female subordination is seen as normal, correct and natural. Where it is difficult to autonomously identify the damage and harmful impacts of power relations on personality and close and community relationships. That is why empowerment must often be promoted by agents of change [5].

For indigenous women is not an easy process because it leads to strengthening and developing skills, abilities, and skills to get highlight of every indian woman his qualities and from the individual to reach to encourage changes in groups that can positively affect their communities, this process of transformation of indigenous women by the way of the residence, fails to meet the goal of training indigenous women, who can influence and drive your life and the lives of their communities; therefore, it also requires addressing strategies to achieve effective equality in all areas of life [28].

Therefore, you must take into account that, "the regulatory framework for the development of strategies aimed at achieving the well-being of indigenous women in equality also implies that they must be guaranteed the respect of the principles of self-determination, full participation, selfgovernment of the indigenous peoples involved the strengthening of the control they have over their territories, as well as non-discrimination, empowerment of women, the physical autonomy, in decision-making, and the right to free, prior and informed consent [8].

In this way, the current dynamics integrated empowerment in the framework of a developed society, is highlighted as elements of the framework, the awareness of the individual and collective capacities, as well as in the current situation of the economic environment, social, political, and environmental. In turn, the acquisition and development of skills that enable participation, individual and/or group, in processes of decision-making on important issues, and the development of a favorable environment that establishes the formal and informal institutions, where you are guaranteed access to information and to facilitate participatory processes of decision making [7].

In this sense, despite the broad international consensus on the fundamental role of indigenous women in the eradication of hunger, malnutrition, social problems, among others. In a world dominated by men, poor in a system that has historically marginalized them and indigenous in societies that discriminate and stigmatize. Therefore, the empowerment that has been developed globally by indigenous women is a precondition for achieving sustainable development [29].

Continuing from the perspective of women's labor participation, it is described that they receive less salary for their participation in the labor market; which dispenses, that they do not receive any remuneration for housework that, in addition, this means a reduction in their time to train as professionals; in cultures of strong patriarchal tradition they are the last to feed themselves and have more difficulties in accessing productive resources [9].

According to the report of the International Labour Organization issued during the sixteenth session of the United Nations Permanent Forum on Indigenous Issues, they describe the importance that decent work can play in empowering indigenous women and men. It should be noted that in their role as workers, entrepreneurs and guardians of their traditions, indigenous women play a vital role in the economic, social, cultural and environmental life of their communities and societies. On the other hand, indigenous women are generally among the poorest of the poor, discriminated against because of their indigenous status and because of their female status [10].

\section{E. Empowerment and socio-productive development in rural areas}

The 1991 Constitution recognizes the existence of three ethnic groups in our territory: indigenous, Afro-Colombian and Rrom or Gypsies. Persons belonging to ethnic groups selfidentify as belonging to one of the above-mentioned ethnic groups. The Afro-Colombians or black communities include in their cultural particularities the Raizales of San Andrés providencia and Santa Catalina and the Palenqueros of San Basilio de Palenque.

In the specificity of the rights of indigenous peoples, the Constitution provides for the constituency, especially to ensure the participation of indigenous peoples in the Senate; recognizes the Special Jurisdiction Indigenous this is his selfrighteousness based on uses and customs; define indigenous territories as a territorial entity with autonomy to the 
management of their interests, the collective ownership of the safeguards; forms of government of the indigenous territories, and the functions of the indigenous Councils, as well as the protection of indigenous territories with respect to the exploitation of natural resources; and, finally, provides that while issuing the organic law of land administration to conform to the Territorial Entities Indigenous referred to in, the Government may issue the tax rules are necessary, and the other relating to the operation of the indigenous territories, and its coordination with the other territorial entities [30]. It should be noted that gender inequalities over time are still high and persistent in all countries. Consequently, the situation of many indigenous women who are subjected to multiple and intersectorial discrimination on the grounds of sex, race, colour and ethnic origin is sad; this situation has led to the deterioration of their living environment, so much so that they are exposed to situations of poverty, violence, multiple forms of discrimination and limitation of their rights [31].

On the other hand, the production of organic coffee and crop diversification plays an important role in the commitment to agricultural sustainability and biodiversity, in this regard, in the department of Cesar there are about 30,000 hectares of coffee planted, with about 8,600 coffee growers, of which $97 \%$ are small producers. Part of this production is marketed as sustainable coffees within the category of specialty coffees [32].

Within this framework, the work of the coffee women of the region is highlighted, as they are the hope of a social construction and a system of decent and remunerated work in the fair trade of products in the world and friendly with the environment. In relationship, the Sierra Nevada de Santa Marta, which presents an approximate altitude of 5000 meters above the sea level, has an ideal climate for the production of organic coffee, taking into account that a small part of this territory covers a significant area of the Department of Cesar and who live in it four native indigenous peoples, such as: the koguis, kankuamos, Wiwas and Arhuacos; these are the descendants of the Tayrona, known as the guardians of the Sierra Nevada. Therefore, organic coffee projects have been integrated and developed taking into account the participation of the indigenous peoples of the region.

The Arhuaco people, especially in their native language is known by the original name Wintukwa; which has a population of about 43,053, active members of the community It has obtained great advances in the production and commercialization of organic coffee through the modality of associativity and have been developing several projects with the participation of the community. Whereas, the importance of women's work in the area of coffee production and organic aware of this global trend to ensure the participation and wellbeing of the indigenous woman coffee in this area of the country, as well as the quality of the product throughout its value chain, the aim is to build a close relationship with the producer Arhuaca of organic coffee, thus being one of the strategic pillars of the community to achieve the millennium development goals [33].

What coffee women can express, will allow them to understand their problems, desires and aspirations, in the same way to become familiar with empowerment and to think as coffee entrepreneurs, guaranteeing food security in their homes. Over the years, the leadership of their women has become evident in the Jewrwa community of the Arhuaco people, examples of empowerment that have been a source of motivation for the new generations. In the same way, working collectively with the support of the community in the pursuit of empowering the future generations, can highlight the efforts of community leaders, entrepreneurs, and even single women who give their all to see arise their cultures, traditions, with the purpose point of view arise your community. In this way, the role of the Arhuaca indigenous woman can be evidenced taking into account that "to empower a woman is to empower a community".

It is of great importance to mention that in the community of Jewrwa there is a seed deposit of empowerment and benchmarks to achieve direct future leaders of the pueblo Arhuaco, however, this does not exclude them from suffering from the social issues day after day affects the society and for them for their double condition of being indigenous and the lack of basic tools to take advantage of those capabilities that they possess.

According to Dusakawi, the Arhuaco people in the Department of Cesar identified malnutrition rates in 33 children, in the different areas of Pueblo Bello, Chimichagua and Valledupar, added to this the number of young people in pregnancy totals 485, identified between 12 and 25 years. Moreover, the educational capacity of the institutions in the territory is low, with only one educational institution with basic secondary training, forcing the inhabitants to defect in search of the complement of higher education, in order to obtain more advanced levels of education [33].

Consequently, this situation for indigenous women in particular is in some cases more difficult since some Arhuaca girls in search of such training leave the community from the age of 13 , to nearby urban localities; and many of them have to reside in family homes as domestic helpers to be able to support their stay and food. In order to be able to advance in their studies they face a very strong problem: as is the new visions of the Western world and the connection they must establish with that environment generates a cultural shock, adapt to the use of technologies, diversity of aptitudes and personalities that are not part of their cultural formation. This is why many young people usually return to the community pregnant or uprooted by new cultural practices and others simply do not return. Consequently, the number of young people who manage to complete their studies and advance to a professional career is very low. Violence in communities such as war between illegal armed groups also poses high risks to the empowerment of indigenous women. 
Therefore, it seeks to generate lines of empowerment and rooting from agricultural activities using as a means the production of organic coffee where awareness can be generated in cultural beliefs and the ability to transform realities from their territory. These issues raise major challenges to promote the empowerment in women Arhuacas and it is considered that through the organic coffee as the main product of the community of Jewrwa, to promote personal empowerment collective, and relations coming, for indigenous women to be able to do part of their community in a constructive, positive and favorable; and for this should begin with the integral formation of their being.

Where a cultural strengthening is generated and against attack on the trends of the current situation that is lived in the sierra Nevada with the indigenous population, loss of culture, displacement of the territory, malnutrition, loss of identity, pollution of the environment, deaths by disease, low levels of schooling, internal conflicts. Among other points that are a primary concern for the indigenous peoples of the Sierra Nevada.

That is to say, the identification of these weaknesses must be worked in order to turn them into strengths if they are oriented in the fulfillment of fundamental axes that are the basis of the culture and the guarantee of its existence, such as love, power and wisdom. For the Arhuacos from their worldview and essence recognize the power of Mother Seynekun who is the one who provides life. For them mother earth and the law of life that guides them is the Law SE, seed of life. Likewise, love through unity among the community is given through the meeting of thoughts, word, action, ancestral knowledge and community experiences, which constitute the legitimacy of collective decisions among the members of the community in all autonomous spaces of deliberation. This makes them a collective subject of fundamental rights.

\section{FINAL CONSIDERATIONS}

Thus it is concluded, that the empowerment, from this perspective, intuitive awareness of their own rights, their capabilities and interests, and of the unequal power relations of persons and social groups, as well as to the further strengthening of their capabilities, confidence, vision and leadership, to drive positive changes in living situations, and even, the political organization to transform these relationships. Hence, in order to promote processes of empowerment, it is necessary to work on the construction of women's autonomy. Traditionally, women are in charge of the care work, learned by inheritance and pre-established social constructs, leaving themselves in the last place, at the service of others.

As they enter a process of empowerment, they begin to realize their choices and ability to make decisions, value their time and recognize their autonomy. There is the challenge between individual empowerment, which refers to the magnitude of personal development that depends on economic, political, social, cultural, educational factors, detached from the collective growth of the group; which under a certain situation can also bring negative factors to some members of the group by creating greater asymmetries and inequalities.

The main recommendation is the creation of spaces for the generation of women's empowerment, where what to do with women is valued, the pertinent relevance is given to the actions and the presence of women in the indigenous community, in addition it is proposed to open spaces for participation and group cohesion where the ideals and opinions of indigenous women are exposed, those who will speak from their experiences and previous knowledge based on their experiences as heads of families and members of the different communities and also will be given the space to project themselves in the future as tools of cultural development where they can be educated and prepared with the premise of being useful for the progress and the good of the community .

\section{ACKNOWLEDGMENT}

To the indigenous women of Jewrwa, who with their effort, determination and empowerment take out day by day the best coffee in the world to give peace of mind to all their families.

\section{REFERENCES}

[1] J. C. Calderón and Martínez Puche, A. Pervivir desde la identidad cultural. Una propuesta de empoderamiento diferencial desde el papel de las mujeres indígenas Nasa en contexto de ciudad. Culturas. Revista de Gestión Cultural, [S.1.], v. 5, n. 1, p. 72-92, jun. 2018. ISSN 2386-7515. Disponible

https://www.polipapers.upv.es/index.php/cs/article/view/9974 doi: https://doi.org/10.4995/cs.2018.9974

[2] C. Uribe Mejía. "Bancarización y empoderamiento femenino". Revista $\begin{array}{lllll}\text { Desarrollo y } & \text { Sociedad, } & \text { n.o } & 75 & \text { (2015): }\end{array}$ https://doi.org/10.13043/dys.75.7

[3] M. León. El empoderamiento de las mujeres: Encuentro del primer y tercer mundos en los estudios de género. Revista de Estudios de Género, La ventana. Vol. 2 Núm. 13. 2001. https://doi.org/10.32870/lv.v2i13.553

[4] I. S. Godínez Rodríguez. Factores Determinantes del Empoderamiento de las Mujeres: Análisis del municipio de santa catarina,N.L Tesis para obtener el grado de maestría en ciencias políticas. Universidad Autónoma De Nuevo León Facultad De Ciencias Políticas Y Administración Pública. 2016. Disponible en https://core.ac.uk/reader/328795811

[5] N. A. Lizana Salas. Las mujeres y el poder colectivo. Análisis crítico del enfoque de empoderamiento de mujeres y la acción colectiva feminista en Chile. Facultad de Filosofía. Programa de doctorado "Ciudadanía y Derechos Humanos" Departamento de Filosofía Teorética y Práctica. Universidad de Barcelona. España. 2014. Disponible en: https://dialnet.unirioja.es/servlet/tesis?codigo $=93138$

[6] Ruiz Bravo, P., Vargas Winstanley, S., \& Clausen Lizarraga, J. Empoderar Para Incluir: Análisis De Las Múltiples Dimensiones Y Factores Asociados Al Empoderamiento De Las Mujeres En El Perú A Partir Del Uso De Una Aproximación De Metodologías Mixtas”. Lima, peru: Instituto Nacional de Estadística e Informática (INEI). 2018. Tomado de: https://www.pucp.edu.pe/idhal/publicacion/empoderar-paraincluir-analisis-de-las-multiples-dimensiones-y-factores-asociados-alempoderamiento-de-las-mujeres-en-el-peru-a-partir-del-uso-de-unaaproximacion-de-metodologias-mixtas/

[7] Álvarez Sánchez, D.; Pardo Gimilio, D.; Isnardo Altamirano, J. Crowdsourcing: A New Way to Citizen Empowerment. En Advances in 
Crowdsourcing. Springer. 73-86. doi: https://doi.org/10.1007/978-3-31918341-1_6 disponible en http://hdl.handle.net/10251/60651

[8] CEPAL. Autonomía de las mujeres e igualdad en la agenda de desarrollo sostenible. 2016.2 Tomado de https://repositorio.cepal.org/bitstream/handle/11362/40633/4/S1601248_ es.pdf

[9] Barrientos, J. La enorme deuda de la humanidad con las mujeres. Marzo de 2018. Obtenido de https://www.eltiempo.com/mundo/masregiones/panorama-de-la-desigualdad-de-genero-en-el-mundo-192402

[10] OIT. La voz y el empoderamiento de mujeres indígenas más importantes que nunca para garantizar un futuro del trabajo mejor para todos. Agosto de 2017. Obtenido de https://www.ilo.org/global/aboutthe-ilo/how-the-ilo-works/ilo-director-general/WCMS_568737/lang-es/index.htm

[11] De la Rosa, L. M. (2019). Paradigmas emergentes en la administración. México, México: Pearson Educación de México, S.A. de C.V. Recuperado el 28 de julio de 2021, de http://cathi.uacj.mx/bitstream/handle/20.500.11961/8253/EBK\%20De\%2 0la\%20Rosa\%20Paradigmas\%20emergentes\%20en\%20la\%20administra cio\%CC $\% 81$ n $\% 2001 \% 20$ SE $\% 20 H A \% 2049652$.pdf?sequence=1\&isAllo wed=y

[12] Eyssautier De La Mora, M. (2002). Metodología de la Investigación. Desarrollo de la Inteligencia. Mexico: ECAFSA.

[13] Hernandez Sampieri, R., Fernandez Collado, C., \& Baptista ILucio, P. (2010). Metodología de la Investigación. México: Mc Graw Hill.

[14] Hurtado De Barrera, J. (2010). Metodología de la Investigación. Bogota - Caracas: SYPAL - CIEA. Quirón ediciones.

[15] Ortega Ospina, A. M. Rol de Naciones Unidas en los procesos de empoderamiento político de las mujeres indígenas en Colombia. Caso de estudio: Mujeres indígenas del Cauca 2010-2015. Bogota: Universidad de los Andes. 2017. Tomado de https://repositorio.flacsoandes.edu.ec/xmlui/handle/10469/11662

[16] Osorio J. W. Esa extraña idea generalizada acerca de la inferioridad de las mujeres. rev.ces derecho. 2015, vol.6, n.2 pp.133-137. Available from: http://www.scielo.org.co/scielo.php?script=sci_arttext\&pid=S214577192015000200010\&lng=en\&nrm=iso . ISSN 2145-7719.

[17] CEPAL. Mujeres indígenas en América Latina: dinámicas demográficas y sociales en el marco de los derechos humanos. 2013. Obtenido de https://www.cepal.org/es/publicaciones/4100-mujeres-indigenas-americalatina-dinamicas-demograficas-sociales-marco-derechos

[18] Molano L., Olga Lucía. Identidad cultural un concepto que evoluciona. Revista Opera [en linea]. 2007, (7), 69-84. ISSN: 1657-8651. Disponible en: https://www.redalyc.org/articulo.oa?id=67500705

[19] Martínez Corona, Beatriz Género, sustentabilidad y empoderamiento en proyectos ecoturísticos de mujeres indígenas. Revista de Estudios de Género. La ventana. 2003, (17), 188-217. ISSN: 1405-9436. Disponible en: https://www.redalyc.org/articulo.oa?id=88401708

[20] Pérez Villar, M.; Vázquez Garcia, V. y Zapata Martelo E. Empoderamiento de las mujeres indígenas de Tabasco: El papel de los fondos regionales de la CDI. Cuicuilco. 2008, vol.15, n.42, pp.165-179. Disponible

http://www.scielo.org.mx/scielo.php?script=sci_arttext\&pid=S0185$16592008000400010 \& \operatorname{lng}=e s \& n r m=i s o$. ISSN 0185-1659.

[21] Zapata-Martelo, Emma, Ayala-Carrillo, María del Rosario. Políticas De Equidad De Género: Educación Para Una Escuela Libre De Violencia. Ra Ximhai. 2014, 10(7), 1-21. ISSN: 1665-0441. Disponible en: https://www.redalyc.org/articulo.oa?id=46132451001

[22] Donawa Torres, Z. A., López Redondo, M. I. y Vega Alfaro, G. E. Enfoques del facultamiento en la Dirección de Impuestos y Aduanas Nacionales de Santa Marta en Colombia. 2017. Revista EAN, 83, pp 167-178. https://doi.org/10.21158/01208160.n83.2017.1820

[23] Sanchez Manchola, I. D. Los estilos de dirección y liderazgo: Propuesta de un modelo de caracterización y análisis. Pensam. gest. [online]. 2008, n.25, pp.1-39. Available from: http://www.scielo.org.co/scielo.php?script=sci_arttext\&pid=S1657$62762008000200002 \& \operatorname{lng}=$ en\&nrm=iso ISSN $1657-6276$.
[24] Xicara Méndez M. del C. Participación y empoderamiento en la política de desarrollo local: Estudio comparado de las formas de participación ciudadana de las comunidades indígenas de Guatemala (2002-2012). Tesis Doctoral, Instituto de Gobierno y Políticas Públicas (IGOP). Doctorado en Políticas Públicas y Transformación Social. Universidad Autónoma de Barcelona 2014. Obtenido de http://www.tdx.cat/bitstream/handle/10803/285163/mdcxm1de1.pdf;jsess ionid=F2534D0E2D2FA3643167C25F44769E1A.tdx1 ?sequence $=1$

[25] Pico Versoza, L. M. El emprendimiento por necesidad, una ventana hacia el desarrollo de oportunidades de negocios. INNOVA Research Journal, 2(1), 131-136. 2017. https://doi.org/10.33890/innova.v2.n1.2017.133

[26] Botello Peñaloza, H. A., Guerrero-Rincón, I. Condiciones para el empoderamiento de la mujer rural en Colombia. En: Entramado. Enero Junio, 2017. vol. 13, no. 1, p. $62-70$ http://dx.doi.org/10.18041/entramado.2017v13n1.25135

[27] Uribe Mejía C. Bancarización y empoderamiento femenino. Revista Desarrollo y Sociedad, n.o 75. 2015. 265-316. https://doi.org/10.13043/dys.75.7

[28] RuizBravo L. P., Vargas Winstanley S. y Cláusen Lizárraga J. Empoderar para incluir: análisis de las múltiples dimensiones y factores asociados al empoderamiento de las mujeres en el Perú a partir del uso de una aproximación de metodologías mixtas. Instituto Nacional de Estadística e Informática (INEI). Lima, Perú. 2018. Tomado de https://www.pucp.edu.pe/idhal/publicacion/empoderar-para-incluiranalisis-de-las-multiples-dimensiones-y-factores-asociados-alempoderamiento-de-las-mujeres-en-el-peru-a-partir-del-uso-de-unaaproximacion-de-metodologias-mixtas/

[29] Inter-American Commission on Human Rights. IACHR. Las mujeres indígenas y sus derechos humanos en las Américas / Comisión Interamericana de Derechos Humanos. 2017. ISBN 978-0-8270-6658-8. Disponible http://www.oas.org/es/cidh/informes/pdfs/mujeresindigenas.pdf

[30] Constitución Política de Colombia. Julio de 1991. Colombia.

[31] M. Rodríguez López, «Los programas de microempresas, una mirada desde las necesidades prácticas y estratégicas de género», Palobra palabra obra, vol. 9, n. ${ }^{\circ}$ 9, pp. 10-24, ago. 2008. https://doi.org/10.32997/23462884-vol.9-num.9-2008-184

[32] Federacion Nacional de Cafeteros - F.N.C. Mujer y Familia: Eje central de la actividad cafetera. 2019. Obtenido de https://www.federaciondecafeteros.org/algrano-fnces/index.php/comments/mujer_y_familia_eje_central_de_la_actividad_ca fetera/

[33] Dusksawi EPSI, A. E. 2019. 